УДК 53.02:004.9:378

\title{
КАК ИЗУЧЕНИЕ ФИЗИКИ НА АНГИЙСКОМ ЯЗЫКЕ ПОЗВОЛЯЕТ ДЕЛАТЬ ПЕРВЫЕ ШАГИ В НАУКЕ
}

\author{
Турабова Лейла Эльбрусовна \\ Миннахметов Фирдус Фидаилевич \\ студенты \\ Научный руководитель: Садыкова Асия Юсуфовна \\ к.физ.-мат.н., доцент \\ ФГБОУ ВО «КНИТУ»
}

Аннотация: Обсуждается методика построения общего курса физики на английском языке с использованием информационных технологий для студентов первого курса. Рассматриваются первые шаги в науке благодаря физике и то, как этот опыт распространяется в школах.

Ключевые слова: Общеобразовательный курс физики. Билингвизм. Информационные технологии. Нанотехнологии.

\section{HOW STUDYING PHYSICS IN ENGLISH ALLOWS TO MAKE FIRST STEPS IN SCIENCE}

\section{Turabova Leila Elbrusovna Minnakhmetov Firdus Fudaulevich Sadykova Asiya Yusufovna}

\begin{abstract}
The method of constructing a general course of Physics in English using informational tecnologies for freshmen is discussed. A first steps in science thanks to Physics and the way how this experience is spread in schools are considered.

Key words: General course of Physics. Bilingualism. Informational technologies. Nanotechnologies.

A question about the further choice of a life path arises before each young person while graduating from the secondary school. A similar question faced the authors of the work, both of whom successfully studied in secondary schools of the
\end{abstract}


two neighboring regions of the Russian Federation, known for their achievements in the field of oil and gas industry: the Republic of Tatarstan (F.Minnakhmetov) and the Republic of Bashkortostan (L.Turabova). The presence of high academic marks at the end of the school education gave the chance of choosing a prestigious university and the corresponding faculty for further education. The choice fell on Kazan National Research Technological University, Faculty of Petroleum and Petrochemistry.

Studying higher education opportunities while beeing the senior students of the secondary school, it is increasingly possible to find offers of either online education abroad, or training in several languages, or the possibility of obtaining diplomas certified in different countries. This modern trend in education concerns mainly humanitarian specialties and is practically absent in the proposals of high school engineering education.

However, education related to IT technologies is gaining popularity among young people, specialties in industries related to oil and gas refining are no less popular in our Republics.

The list of opportunities provided by the Faculty of Petroleum and Petrochemistry of Kazan National Research Technological University to its students is extensive, including various specializations and, among other things, there is an opportunity to study subjects in English.

Two academic groups are formed from the best future freshmen of this faculty, whose students study the curriculum subjects in English.

Despite the fact that the students in these groups were selected in accordance with their wishes and according to school scores in a foreign language, nevertheless, the level of knowledge of a foreign language left much to be desired.

Language school knowledge was clearly not enough to study complex subjects such as Higher Mathematics, Physics, General and Inorganic Chemistry, Organic Chemistry, etc. A number of students after the first week of study preferred to apply to the dean's office with a request to transfer to groups with education only in Russian.

One of the most difficult subjects for freshmen is Physics. A high level of knowledge requirements on this subject was set at the first lecture. Both at the lecture and at the first practical lesson in Physics, the requirements of skills for specialists of the third decade of the XXI century were voiced, regardless of the branch of economics and knowledge that were developed by the World Economic Forum in Davos [1], which forced almost every student to determine their responsible attitude to the subject. 
Table 1

\section{Actual skills of the XXI century declared by the World Economic Forum in Davos}

\section{Top skills in 2020 shift to Critical Thinking, Creativity and Emotional Intelligence}

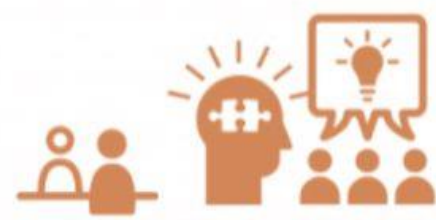

in 2015

1. Complex Problem Solving

2. Coordinating with Others

3. People Management

4. Critical Thinking

5. Negotiation

6. Quality Control

7. Service Orientation

8. Judgment and Decision Making

9. Active Listening

10. Creativity

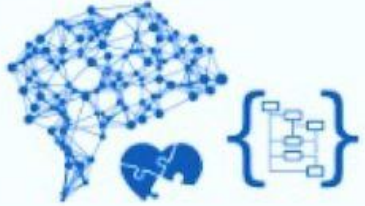

in 2020

1. Complex Problem Solving

2. Critical Thinking

3. Creativity

4. People Management

5. Coordinating with Others

6. Emotional Intelligence

7. Judgment and Decision Making

8. Service Orientation

9. Negotiation

10. Cognitive Flexibility

Source: Future of Jobs Report, World Economic Forum, 2016

During the classroom lessons, it was explained very clearly that, using the example of knowledge in Physics, the skills listed in Table 1 will be developed that will make students competitively capable and in-demand specialists in the future. In addition, each topic of the lectures was considered from the standpoint of the need for subject knowledge for subsequent courses and the connection with those disciplines that were studied in parallel with the Physics course. This information made each student be responsible to find the way to coincide the teacher's requirements for the subject.

The lectures and practical classes also dealt with those physical inaccuracies and even errors that can be found on the Internet and in the literature when studying individual topics of lectures. This constant work effectively formed critical thinking, one of the main skills that both a modern engineer and a specialist in any industry should possess.

Active knowledge of physical terminology in English was formed within the framework of practical classes in Physics (Fig. 1). 


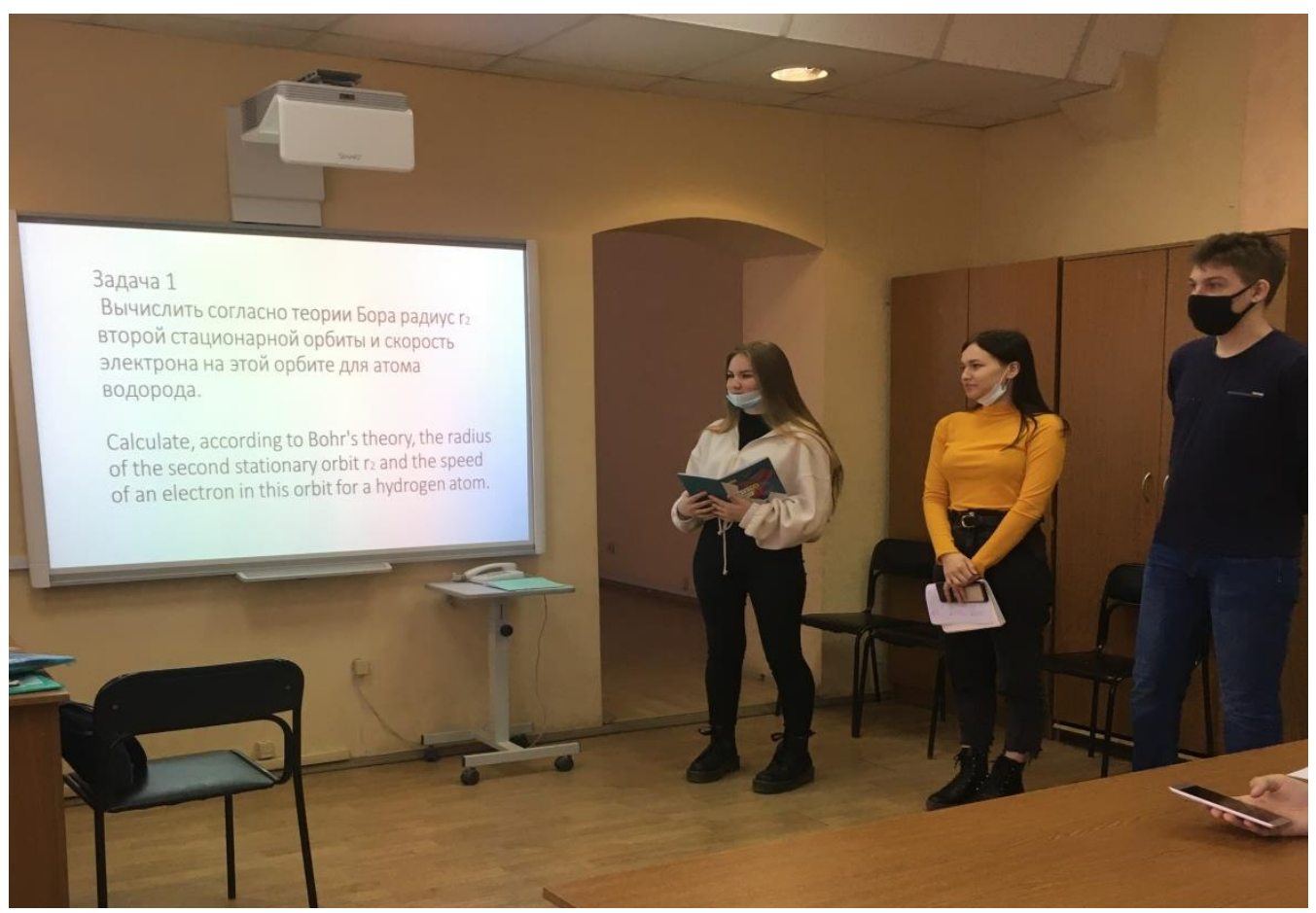

Fig. 1. Protection of the solution of the hometask by a team of students in English

There was no opportunity to relax, since the whole group was divided into teams, and each team was offered its own version from the list of practical home tasks in various sections of the Physics course.

The use of interactive technologies, electronic whiteboards and presentations on completed tasks has changed the rhythm of classes. At each lesson, each team reported orally in English on the work done: translating the text into English, solving and working on units of measurement.

The use of an electronic whiteboard and presentations stimulated each of the students to use the opportunities for a better presentation of materials, to study of the possibilities of software, up to the inclusion of animations of physical processes.

It must be emphasized that innovative technologies were constantly used in the course of training: information and communication technologies (ICT) in subject training; information and analytical support of the educational process and quality management of education; monitoring of intellectual development; didactic technologies. All this helped to build a more structured training format. Thanks to this approach, classes are very interesting and informative, and more material is analyzed in a short time, active practical exercises and independent creative work on tasks allow the knowledge gained to be thoroughly realized.

Since the study of Physics took place in a foreign (English) language, it radically changed the perception of the material. Translating everything heard and 
read from one language to the familiar one, and repeating all the material several times in order to clearly speak in practical classes, each student comes to a situation of deeper and more effective assimilation of the material, there is a conscious rejection of mechanical memorization of the text.

By the end of the first semester, almost all freshmen acquired the skills of oral presentations and high-quality presentation of subject material in the form of oral accompaniment of electronic presentations. As part of the Physics course, an understanding was also formed that any task should be approached from a scientific point of view.

The introduction to public speaking was one of the ways to attract students to the study of the subject and to scientific knowledge. The speaker should be confident in his knowledge and well versed in this topic, since he becomes a source of true information. Speaking with a certain topic, it is necessary to convey it to the audience in such a way that this material is understandable and accessible to everyone, which makes it actual to explore more material and understand it well. At the same time, thoughts are correctly formulated, oral speech is honed, confidence appears.

In the middle of the first semester, the teams were tasked with studying one of the most relevant modern scientific directions - nanotechnology [2]. The list of topics offered to students is given in Table 2 .

Table 2

\section{List of conference topics}

Molecular rotor. A molecular manipulator. Nanomotors. Graphene. Ionistor. Nanocrystals and nanoclusters. Princetechnology. Plasmons. A wearable electricity generator. Molecular propeller. Invisibility cloaks. Plastic electronics. Negative refraction. Nanoporous structures. Nanofluidics. Nanomaterials in everyday life. Biomimetics in nanotechnology. Unusual optical nanomaterials. Nanomaterials in construction Nanomaterials in materials science.

Nanomedicine. Nanotechnology in petrochemistry. Nanotechnology in agriculture

After the preparation of the reports, a scientific conference was announced for the groups that studied Physics in English.

Since limited time was allocated for the report, it was necessary to thoroughly work out new material and think over the effectiveness and visibility of the electronic presentation.

There were a lot of speakers among the freshmen, so during the compressed time of the conference, students got acquainted with a fairly extensive amount of new and useful scientific information. 
After each report, the Physics lecturer analyzed the quality of the electronic presentation, the scientific novelty of the material presented, the relevance for the chosen profession and for implementation. The speakers had to finalize the material in accordance with the comments made by the lecturer. Then everyone was recommended to speak with the material presented during the conference at the school the freshmen graduated from during the students winter holidays.

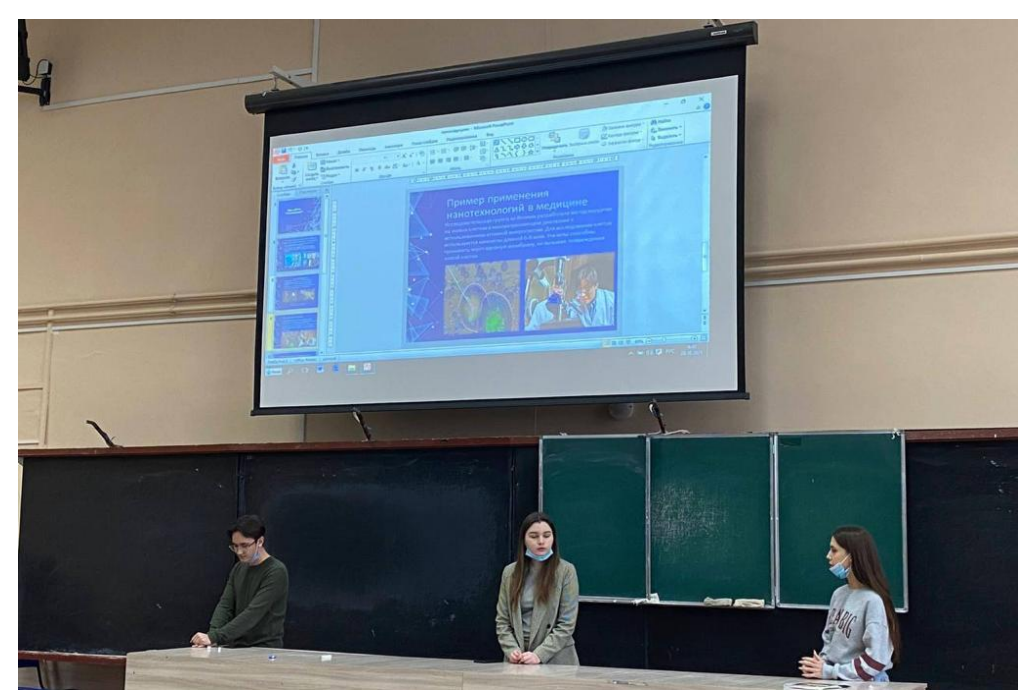

Fig. 2. A team of freshmen presents a scientific report at a Physics conference

The teams in which worked the authors of the article on this task prepared the topics: Negative refraction and Nanofluidics.

Inspired by the new experience and knowledge gained, it was decided to visit native schools of the authors and share this knowledge with the senior students of school.

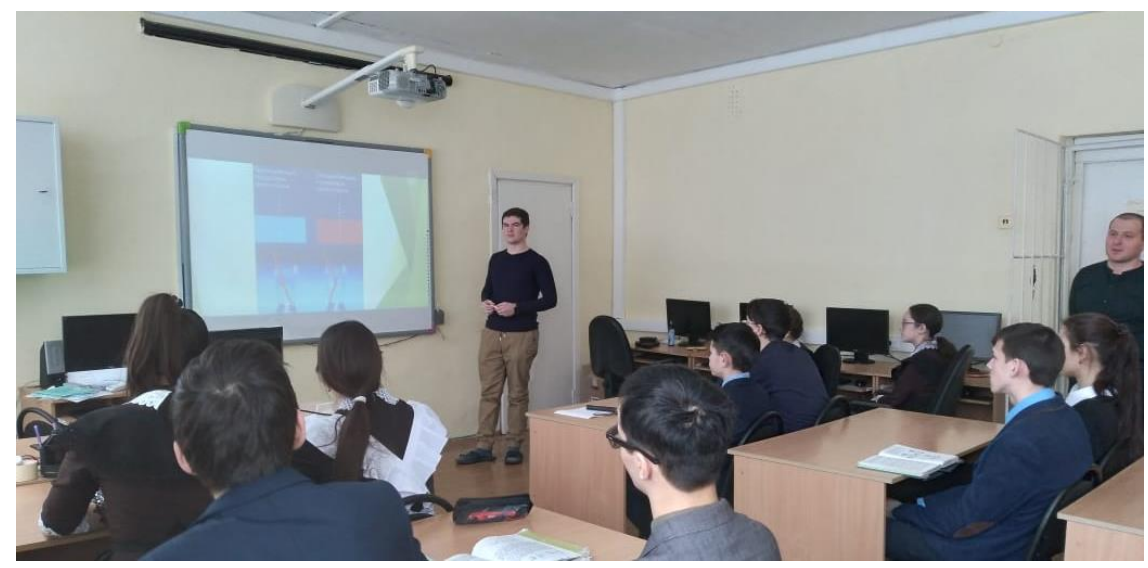

Fig. 3. The report of Minnakhmetov F. "Negative refraction" at the Secondary school of "Novo-Aryshskaya" of the Rybno-Slobodsky municipal district of the Republic of Tatarstan 
Figures 3 and 4 show photographs taken in the process of corresponding reports.

To our surprise, even teachers, despite their teaching experience, reacted with great interest to this information, recognizing that for them such concepts as "Negative refraction" and "Nanofluidics", which can help in the fight against many diseases, are new and unfamiliar information.

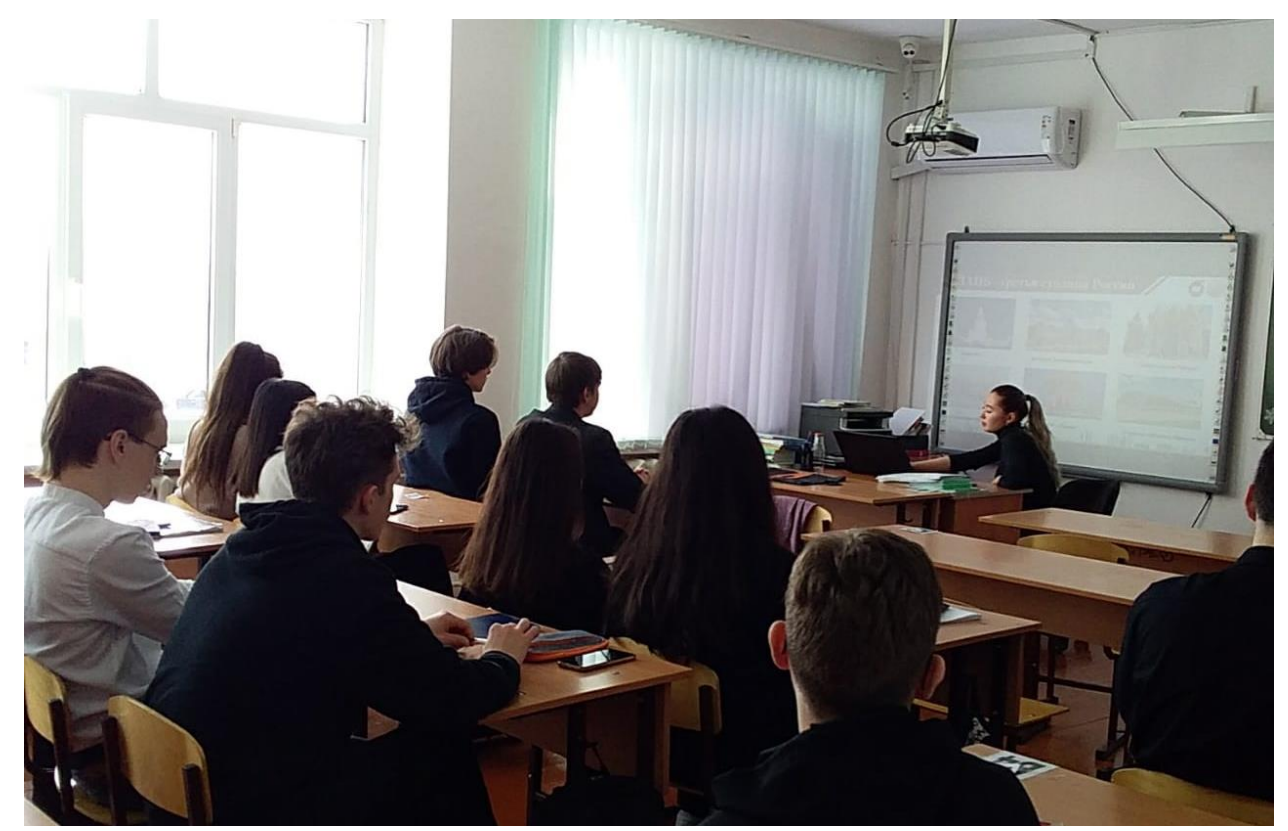

Fig. 4. Report of Turabova L. "Nanofluidics" at the Scondary school № 2 of the village of Akyar of the Khaibullinsky district of the Republic of Bashkortostan

The attention with which the senior students (of the schools) listened to the information on Physics, the questions asked and the interest in the topic gave us confidence in the relevance of our work, interest in science. In addition, there were many questions about the University where we study.

In conclusion, it should be noted that thanks to studying Physics in English, not only solid knowledge of Physics was acquired, but also skills of non-standard thinking, the level of foreign language proficiency increased. Imperceptibly, but in short time critical thinking was formed, the experience of public speaking was acquired and the gift of social activity was opened.

Having discovered a lot of new and useful information, one enthusiastically shared the knowledge and experience that were acquired during the subject training at the Kazan National Research Technological University. It makes us ready to make next steps in science. 


\section{References}

1. The Future of Jobs. Employment, Skills and Workforce Strategy for the Fourth Industrial Revolution. Global Challenge Insight Report . World Economic Forum Cologny/Geneva .Switzerland -2016. p.1-159/

2. Садыкова А.Ю. Педагогические приемы в рамках курса физики, формирующие критическое мышление у студентов факультета «наноматериалов и нанотенхнологий». // Вестник Каз.техн.унив. - 2014.- т. 17. № 20.- C. 340-343. 